University of Nebraska - Lincoln

DigitalCommons@University of Nebraska - Lincoln

Faculty Publications: Department of Teaching, Department of Teaching, Learning and Teacher Learning and Teacher Education

Education

7-2013

\title{
The ideologies behind newspaper crime reports of Latinos and Wall Street/CEOs: A critical analysis of metonymy in text and image
}

\author{
Theresa Catalano \\ University of Nebraska-Lincoln, tcatalano2@unl.edu \\ Linda R. Waugh \\ University of Arizona, Iwaugh@u.arizona.edu
}

Follow this and additional works at: https://digitalcommons.unl.edu/teachlearnfacpub

Catalano, Theresa and Waugh, Linda R., "The ideologies behind newspaper crime reports of Latinos and Wall Street/CEOs: A critical analysis of metonymy in text and image" (2013). Faculty Publications: Department of Teaching, Learning and Teacher Education. 140.

https://digitalcommons.unl.edu/teachlearnfacpub/140

This Article is brought to you for free and open access by the Department of Teaching, Learning and Teacher Education at DigitalCommons@University of Nebraska - Lincoln. It has been accepted for inclusion in Faculty Publications: Department of Teaching, Learning and Teacher Education by an authorized administrator of DigitalCommons@University of Nebraska - Lincoln. 
Published in Critical Discourse Studies 10:4 (2013), pp. 406-426; doi: 10.1080/17405904.2013.813774

Copyright (C) 2013 Taylor \& Francis. Used by permission.

A short, earlier version of this paper was presented at the annual meeting of the American

Association of Applied Linguistics in Boston, Massachusetts, on 24 March 2012.

Published online July 30, 2013.

\title{
The ideologies behind newspaper crime reports of Latinos and Wall Street/CEOs: A critical analysis of metonymy in text and image
}

\author{
Theresa Catalano ${ }^{1}$ and Linda R. Waugh ${ }^{2}$
}

1. Department of Teaching, Learning and Teacher Education, University of Nebraska-Lincoln, Henzlik 118, Lincoln, NE 68588, USA; Corresponding author - email tcatalano2@unl.edu

2. Departments of French and Italian and English: Interdisciplinary Ph.D. Program in Second Language Acquisition and Teaching, University of Arizona Tucson, AZ 85721-0067, 626-807, USA

\begin{abstract}
This study illustrates how metonymy in image and text work together to produce dominant ideologies in US media discourse, through careful, multidisciplinary analysis of over 25 articles in online US newspapers from the years 2004 to 2011 that reported crimes committed by Wall Street/CEOs and Latino migrants. Using critical discourse analysis/ studies, multimodal analysis, and cognitive linguistic frameworks, we examine examples of metonymy, which combine to negatively "Other" Latinos and (re)produce positive representations of Wall Street/CEOs. While work in critical metaphor analysis shows how metaphor plays a crucial role in the depiction of participants and events, we argue that metonymy is equally important and reveals the need for a critical metonymy analysis. These results help to demonstrate the ideological potential of metonymy in media discourse and how it contributes to the public's conceptualization of these groups, thereby bringing us one step closer to social justice and social change.
\end{abstract}

Keywords: crime reports; Latinos; CEOs; metonymy; ideology

\section{Introduction}

The way individuals or groups and their actions are represented in the media can play an important role in how they are perceived by the general public, especially where they have no direct personal experience of such persons. This can then lead to important consequences for the lives of those represented, especially so when these persons are particularly powerless. In this paper we address the way that the US news media represent two groups of persons and their actions - who indeed have very different access to power and resources - and how such reporting maintains and legitimizes definitions of crime and criminality that serves the interests of corporate capitalism. In this case we are interested in the way that crimes committed by Wall Street CEOs and Latino migrants are represented in very different ways. We show how carrying out a multimodal analysis of metonymy in text and image can reveal less-than-obvious discursive strategies that (re)produce dominant ideologies of criminality and crime. In the case of Wall Street CEOs and other corporate criminals, a positive representation of accused individuals in crime reports downplays actual crimes they committed, thereby leading the public to underestimate the impact of corporate crimes and to allow the continuation of 
de-regulation and other lax laws that govern corporations and their CEOs. On the other hand, reports depicting crimes committed by Latino migrants (the majority of whom are from Mexico) paint an unfavorable portrait of this group as a whole, which is then employed as a justification for harsh immigration policies.

\section{Theoretical basis}

The theoretical frameworks and the tools they provide that underlie this investigation are multiple. However, three are the most important: critical discourse analysis/critical discourse studies (CDA/CDS), multimodal analysis, and conceptual metaphor/metonymy in cognitive linguistics (CL). The combination of CDA/CDS and metaphor/metonymy is found in several studies: for example, Charteris-Black (2004), Maalej (2007), Hart (2008, 2010), Musolff (2012), and Santa Ana (2013). There are a few who combine CDA/CDA, metaphor, and multimodality in Critical Multimodal Metaphorical Discourse Analysis (Catalano, 2012; Hidalgo-Downing \& Mujic, 2011). However, there are only a few examples of the incorporation of metonymy with CDA (Meadows, 20071), and none that we know of, except for Catalano and Waugh (2013), that constitute Critical Multimodal Metonymic Discourse Analysis, the main focus of this paper.

CDA, based originally on critical linguistics, as outlined in Fowler, Hodge, Kress, and Trew (1979), "show[s] how language and grammar can be used as ideological instruments" (Machin \& Mayr, 2012, p. 2). It was born out of arguments that a link should be made between language, power, and ideology (Fairclough, 1992) and that the analyst should reveal, in particular, the ideology/ies hidden in a given text and reveal his/her own position, to the point that, for some, a moral or political evaluation is given and a commitment to social change and political action is made. Recently, CDS has called for a broader view, urging others to "go beyond established enclaves of specialized work on discourse" (Fairclough, Graham, Lemke, \& Wodak, 2004) and we view our work as fitting into this broader definition.

Like many other scholars in (critical) discourse analysis/studies, we embrace work on multimodal (especially verbal and visual) analysis, since the texts we analyze here and in other publications typically include at least a photograph/image. As many have argued, any analysis of a text must take into account the way(s) in which its visual features contribute to its overall meaning; thus the analyst should do a detailed and systematic analysis of the visual aspects of the text and their relation to the linguistic aspects (Hodge \& Kress, 1988; Machin \& Mayr, 2012). Combining multimodality with CDA has led to multimodal critical discourse analysis with a commitment to an ideological analysis of the images themselves and their meaning potential in relation to the text; the present authors view our work as contributing to this emerging approach.

Since the publication of Lakoff and Johnson's Metaphors we live by (1980), many scholars in CL have been drawn to see metaphor as the main "cognitive mechanism guiding human conceptualization" (Barcelona, Benczes, \& Ruiz de Mendoza Ibáñez, 2011, p. 1), although we see this as socio-cognitive, since cognition is tightly connected to social interaction (Van Dijk, 2009). While metonymy is traditionally viewed as just one of many tropes and subservient to metaphor, much recent work in CL argues that metonymy too is a fundamental part of the conceptual system (Gibbs, 1994, p. 319), shapes the way we think and speak of ordinary events (Gibbs, 1999, p. 61), and, along with metaphor, is used for drawing inferences and for reasoning about and understanding the world (Ruiz de Mendoza Ibáñez \& Perez Hernández, 2003, p. 24). Therefore, the importance of metonymy as a window into the perception of individuals and groups should not be underestimated.

We are in agreement with the many scholars in CL who argue that while the two conceptual strategies are similar because they affect or reflect our perception of people and events, they are different kinds of processes (see also Benczes, Barcelona, \& Ruiz de Mendoza Ibáñez, 2011; Dirven \& Pörings, 
2002; Gibbs, 1994). Thus, in an example like, "Our biggest enemy right now is inflation." (Lakoff \& Johnson, 1980, p. 33), inflation (an abstract concept having to do with the value of money) is personified (a type of metaphor), and compared to an opposing force, an enemy, that might hurt or destroy us and therefore we must take action against it. This is based on the metaphor INFLATION IS AN ADVERSARY where two things are compared (inflation and adversaries) that are not alike in most ways, but similar in one particular aspect: they can hurt us. By contrast, in an example like "Illegal immigration costs U.S. taxpayers about \$113 billion a year at the federal, state and local level." (Martin \& Ruark, 2010/2011), the words illegal immigration and taxpayers illustrate the metonymies of ACTION FOR AGENT, in which immigration stands for the immigrant, and DEFINING PROPERTY FOR CATEGORY, because the term illegal calls attention to the way the immigrants entered the USA and the use of taxpayers gives metonymic prominence to one duty of citizens, which is to pay taxes, and ignores other duties that are not relevant to the context (such as voting). It also calls attention to the financial losses of the average citizen and the burden of these immigrants on the public.

There has been much debate about the definition of metonymy. We define it as a mapping where a source (in the example above, citizens) provides access to a target (taxpayers) because there is a perceived spatial, temporal, experiential, or conceptual contiguity (connection, association) between them (Dirven, 2002; Jakobson, 1956). In addition, we agree with the view that the source for the metonymy imposes a conceptual perspective on, and thus activates, the target, which then causes a shift in (conscious or unconscious) attention from source to target and results in the target being foregrounded while the source is backgrounded (Benczes, 2011, p. 199; Panther \& Thornburg, 2003, p. 7).

Some other examples of metonymy include PART FOR WHOLE/WHOLE FOR PART (synecdochic) relations, as in: "She's just another pretty face," "They're looking for some new blood," and "We live in America." Metonymy encompasses a wide variety of types, including complex conceptual interactions with metaphor in which metonymy functions to develop or highlight the source or the target of a metaphor (to be discussed further in the Data Analysis section of this paper).

Like metaphor, metonymy occurs not just in (verbal) text and talk but in image as well. The following photographs taken from online news sources illustrate the symbolic use of image.

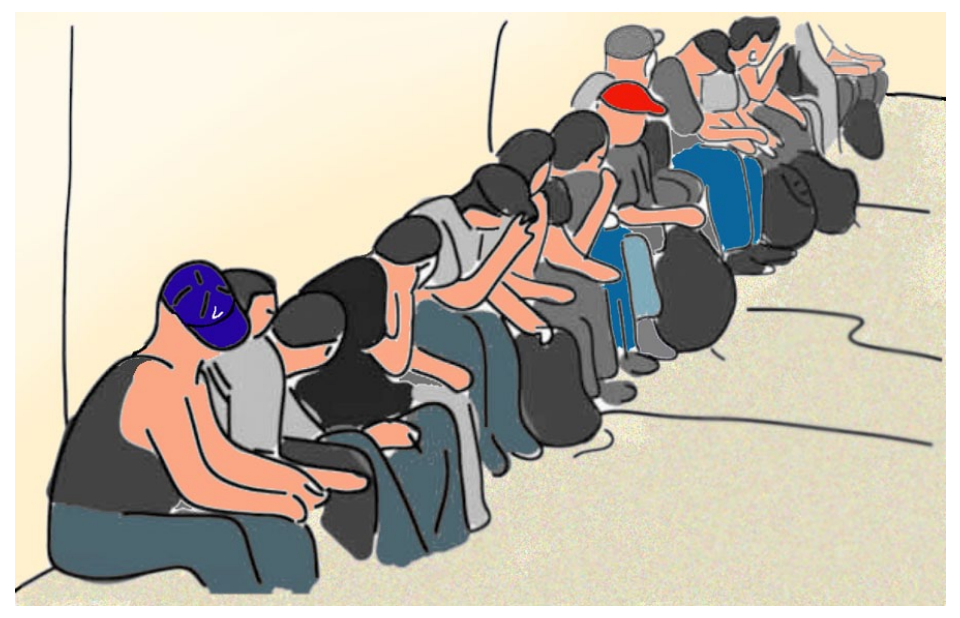

Photo 1. Obama Administration to Allow Many Illegal Aliens to Stay This drawing is similar to the photograph in the original article. View the original photo at: http://www.gopusa.com/ news/2011/08/19/obama-admin-to-allow-many-illegal-aliens-to-stay

In the first image (with the headline "Obama Administration to Allow Many Illegal Aliens to Stay"), the long line of men sitting on the floor metonymically symbolizes the endless number of peo- 
ple supposedly trying to get into the USA illegally. This is an example of functionalization, in which the participants are reduced to just one action: trying to enter (Khosravanik, 2010, p. 13). It is also an example of homogeneous collectivization because they are shown as a group and not important as individuals (Ibid). The fact that the men are all facing away from the camera shows that we are neither meant to get close to them nor find out their thoughts and feelings about the issue nor even see them as people, since the face is (metonymically) the most salient way in which we identify others. Because we cannot see their faces, they are faceless and not really people. The downward camera angle conveys disempowerment and represents the migrants as "below us." Moreover, the immigrants in the photo are "construed as a permanent threat, as a conflict between us and them, between those who want to get in and do not belong here, and those of "us" who belong here" (Van Dijk, 1987, p. 219). The photograph below is in stark contrast to the photo of the migrants above.

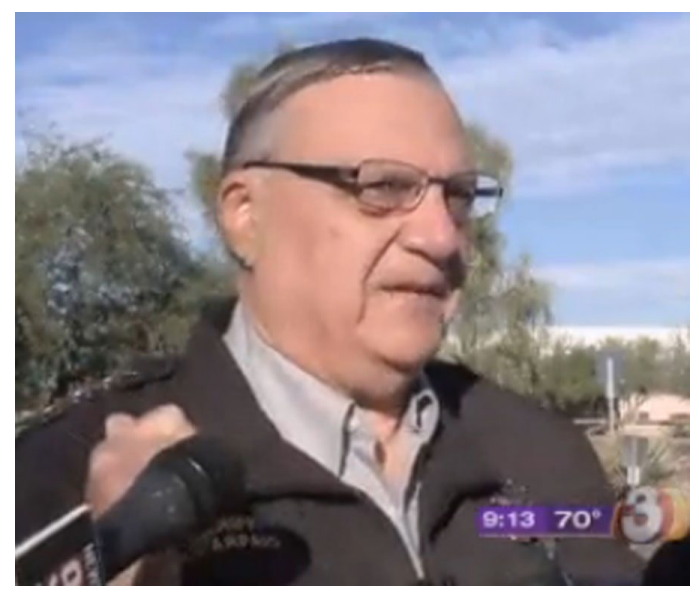

Photo 2. Sheriff Joes Fights Back: Appealing Court Ruling Barring Arrest of Hispanic Illegal Aliens. Retrieved from: http:/ / usopenborders.com/2012/01/sheriff-joe-fights-backappealing-court-ruling-barring-arrest-of-hispanic-illegal-aliens /

Here Sheriff Joe Arpaio (well documented for human rights violations against immigrants in Arizona) is shown in a close-up shot, which individualizes him and symbolizes a closeness and familiarity with him and thus (metonymically) law enforcement in general. Second, the eye-to-eye view of the vertical camera angle implies equality (in contrast to the downward camera angle shown above).

Before discussing the data in detail, we next turn to the methods used in this study.

\section{Method}

All texts analyzed were published between the years 2004 and $2011^{2}$ and found by www.google. com searches using keywords germane to this analysis. ${ }^{3}$ The data were divided into Wall Street/ CEO and Latino crime report texts and images. In both cases, the articles meet the criterion of being firsttime crime reports, and thus their main purpose is to reveal the facts of the crime. The selection of "first-time crime reports" as opposed to articles discussing opinions about crimes was strategic in order to demonstrate the ideology-carrying capacity of news genres that the public generally considers to be "fact-giving" and not "opinion-giving," which makes the deconstruction of these texts much more necessary.

In the case of Wall Street/CEO crimes, reports were searched by names of people and their companies accused of well-publicized corporate crimes. These names included Bernie Madoff, Martha 
Stewart, Goldman Sachs, and others. Corporate crimes included fraud, conspiracy, and insider trading. Because these cases received so much publicity, they were found in very well-known prestigious American newspapers (online) such as the Wall Street Journal, New York Times, Washington Post, as well as less prestigious local papers. As said above, seven out of 11 articles were found in the "business" sections of the newspapers (which according to Clinard \& Yeager, 2006 is common practice), while three of the crimes were found under the "news" sections, for a combined total of 13,125 words. In addition, the articles reporting CEO crimes were much longer and more detailed than the articles reporting crimes committed by Latinos, and thus although fewer articles discussing CEO crimes were examined (11 as opposed to 16 articles reporting Latino crimes), the CEO text size is still more than double that of the articles reporting crimes by Latinos. This could be attributed to the wide coverage of these highly publicized crimes (note that if they were not publicized they would not have been found easily) or because of the devastating effects they had on society.

For the Latino crime reports, 16 texts were found from online papers such as the Denver Post, L.A. Times, and Arizona Daily Star. Articles were found by searching for the words "migrant," "migrant worker," "immigrant," "illegal immigrant," "undocumented immigrant," "illegal alien(s)," and other terms used to identify migrants. They were paired with names of common crimes such as "assault," "murder," "burglary," etc. Crimes committed by Latino migrants included rape, burglary, carjacking, and assault with a total of 5273 words.

As per Santa Ana (1999) metonymies relating to the representation of CEOs or Latino migrants were categorized as "positive" or "negative" (according to their portrayal of the subject), while metonymies that had debatable effects on the portrayal of the subject were classified as neutral and not included. Once categorized as "positive" or "negative" the metonymies were tabulated according to type (listed in the appendix). In the results section of this paper, salient examples of the metonymies are presented and discussed with the categorizations listed in order of appearance. A total of $20 \mathrm{im}-$ ages were found among the CEO and Latino articles (16 from CEO articles and 6 from Latino articles). ${ }^{4}$ While all images were analyzed for metonymies and can be found in the appendix, only a representative sample is discussed here (four from the CEO articles and two from Latino articles), due to the scope of this paper. Next, metonymies relating to the representation of CEOs or Latino migrants in images were extracted, classified, tabulated (included in tables in the appendix), and presented in the results section as mentioned above. In an additional note, it is important to acknowledge the important role that metaphor plays in our data and thus we will discuss briefly some of the metonym/ metaphor interactions found in the paper. However, because this paper's purpose is to highlight the importance of metonymy, we will focus on the metonymies.

\section{Analysis of CEO crime reports: Texts}

Corporate crime can be defined as "the deviant activities of respectable institutions, corporations and individuals" (Mayr \& Machin, 2012, p. 199). In the criminal justice system, white collar and corporate crimes are considered a special breed and treated differently because unethical acts resulting in devastating effects for many people have not been made illegal (Gustafson, 2006, p. 685). Because corporate crimes can be violations of administrative and civil law (as well as criminal law), often they result in fines rather than prison time, to which less stigma is attached. Corporate law violations (with the exception of very large ones such as Enron, WorldCom, and others found in this analysis) are not highly publicized on the whole and rarely come to the attention of the public through the press and TV. Studies have shown that nearly all publicity of corporate law violations are found (buried?) in the business section of newspapers and there is far less information about this type of crime than there is about "common" / "street" crime (Clinard \& Yeager, 2006, p. xi). Unlike other kinds of crime (such as those found in the Latino crime reports) "in- 
formation about corporate crimes is not so easily provided to journalists by the usual definers of crime, the police" (Mayr \& Machin, 2012, p. 199). Another important difference found in corporate crime reports is fewer quotes from police officers and more from legal people familiar with the sector (such as the Securities and Exchange Commission [SEC]) or lawyers of the defendants. Lawyers are known to cost a lot of money (a sign of privilege), and fight vigorously for their clients, and thus they work in favor of corporate crime; whereas police are agents of the municipality, have no positive attachment to street criminals (such as immigrants), and are part of the prosecution. As a consequence, except for very large cases that come to general attention, the perception has been that corporate law violations are not nearly as serious or numerous as conventional crimes, which get nearly all the publicity. This is due in part to the fact that laws regulating corporate behavior are often vague and open to interpretation by those violating them (Mayr \& Machin, 2012, p. 204). In actuality, corporate crime has a much larger effect on society than conventional offences (Clinard\& Yeager, 2006, xi). In the case of this analysis, most of the articles come from highly publicized cases, in which unusually harsh punishments were doled out, yet the results (see Tables A1 and A2 for a list of metonymies found) show a positive portrayal of CEO's / corporate criminals convicted or accused of crimes such as fraud. Due to the purpose of this paper, to show the ideological potential of metonymy, only salient examples of the metonymies used in these positive portrayals will be examined.

We will first begin with examples from the written texts and then move to images to illustrate how the two interact.

\section{Text 1. Jail terms for 2 at top of Adelphia ${ }^{5}$}

(1a) "I apologize - this whole thing has happened to all of us," he said. "There are many things that I wish I had done differently." (SIMPLIFIED EVENT FOR COMPLEX SUB-EVENTS (whole thing), WHOLE FOR PART (all of us, many things))

(1b) Upon leaving the courtroom, John and Timothy Rigas diverged to opposite sides of the hallway - the son huddling with his lawyers on one end while the father, looking overwhelmed, congregated with family on the other. "You did a very nice speech up there," said an elderly friend, hugging John Rigas. (DEFINING PROPERTY FOR PERSON (all of the examples))

The above examples demonstrate the use of metonymies such as SIMPLIFIED EVENT FOR COMPLEX SUB-EVENTS (e.g. whole thing - a neutral term - stands for the crime committed, in this case, fraud, and "many things that I wish I had done differently" meaning the crimes) and WHOLE FOR PART ("happened to all of us"; in fact, the crime did not "happen" to the social actor, it was committed by the social actor). Also, what "happened" could be different depending on whether it is the perpetrator (being found out, going on trial, being convicted) or those who were defrauded (losing their money). In addition, the common metonymy of DEFINING PROPERTY FOR PERSON/CATEGORY proves to be effective in highlighting the family members of the accused, as well as elderly friend, which often has a positive connotation and leads to a positive representation of the subject. These metonymies represent what Mayr and Machin refer to as "neutralization techniques," which are verbal accounts through which deviants mitigate and justify their criminal conduct. These techniques allow executives to violate the law without feeling guilty and without damaging their nondeviant self-image (2012, p. 204).

The following examples illustrate metonymies of DEFINING PROPERTY FOR PERSON again as well as SIMPLIFIED EVENT FOR COMPLEX SUB-EVENTS. 


\section{Text 3. Top broker accused of $\$ 50$ billion fraud}

(3a) Dan Horwitz, a lawyer for Mr. Madoff, declined to elaborate on the allegations. "Bernard Madoff is a longstanding leader in the financial-services industry with an unblemished record," (JOB FOR PERSON (lawyer), DEFINING PROPERTY FOR PERSON (longstanding leader, Mr. Madoff), PART FOR WHOLE (unblemished record))

(3b) Mr. Horwitz said in an interview. "He is a person of integrity. He intends to fight to get through this unfortunate event." (DEFINING PROPERTY FOR PERSON (person of integrity), SIMPLIFIED EVENT FOR COMPLEX SUB-EVENTS (unfortunate event))

(3c) The next day, the sons met with Mr. Madoff at his office to ask about the bonus situation because he had appeared to be under "great stress" in prior weeks, they told the FBI. (DEFINING PROPERTY FOR PERSON (sons, Mr. Madoff), PROPERTY FOR PERSON (bonus situation, under "great stress"))

(3d) Mr. Madoff "wasn't sure he would be able to hold it together" if they continued to discuss the issue at the office, the complaint quotes one of the sons as saying. (DEFINING PROPERTY FOR PERSON (Mr. Madoff), PART FOR WHOLE (it), SIMPLIFIED EVENT FOR COMPLEX SUB-EVENTS (issue), DEFINING PROPERTY FOR PERSON (sons))

The above examples establish the positive representation of the subjects through metonymies about the subject's record and his personality (e.g. longstanding leader, unblemished record, person of integrity) along with formal register (with the use of $M r$., a term of respect). In addition, the metonymies of SIMPLIFIED EVENT FOR COMPLEX SUB-EVENTS hide the true magnitude of the crime by referring to them with neutralizing words such as the issue, situation, and unfortunate event and to his mental state as an it, in the case of holding it together. Additionally, terms like "unfortunate event" replace the discourse of crime with the discourse of a tragedy or accident. This in turn helps the reader to view the event in a non-criminal way.

\section{Text 5. WorldCom's Ebbers convicted}

(5a) Ebbers, a former milkman and high-school coach who built WorldCom from a tiny Mississippi longdistance reseller into a national powerhouse, is the fifth and highest-ranking World- Com executive to be convicted in the fraud. (JOB FOR PERSON (milkman, high-school coach), DEFINING PROPERTY FOR CATEGORY (national powerhouse, highest-ranking World Com executive, fraud))

(5b) His wife, Kristie, ${ }^{6}$ cried quietly throughout the reading of the verdict, and, after it was finished, Ebbers walked over and put his arms around her and their daughter. (DEFINING PROPERTY FOR PERSON (wife, daughter), WHOLE FOR PART (her, daughter - as opposed to their shoulders))

(5c) Then he and his family left the Manhattan courthouse together, pushing through a scrum of reporters who peppered him with questions. Silent and still impassive, he and his family climbed into a taxi. (DEFINING PROPERTY FOR PERSONS (he and his family [used twice]), INSTRUMENT FOR ACTION (peppered)

In the above examples, Bernard Ebbers is represented positively with metonymies highlighting 
his humble beginnings, former careers, current rank, company status, and his family ties. Example (5c) illustrates the metonymy of INSTRUMENT FOR ACTION (pepper stands for the action of questions coming at him from all sides, quickly, and giving him little chance to respond) and the reference to the reporters as a scrum ${ }^{7}$ presents the reporters negatively (which as a result makes Ebbers look good) and lends a sympathetic tone toward the subject. The following examples illuminate the use of metonymy to represent Goldman Sachs.

\section{Text 7. Goldman Sachs charged with fraud}

(7a) CEO Lloyd Blankfein has drawn heat for Goldman's rich pay and profits in the wake of the taxpayer bailout of the financial system. (JOB FOR PERSON (CEO), PHYSIOLOGICAL RESPONSE FOR EMOTION (heat), INSTITUTION FOR PERSON (Goldman's), DEFINING PROPERTY FOR CATEGORY (rich pay, profits), RESULT FOR ACTION (bailout), INSTITUTION FOR PERSONS (financial system))

(7b) "As much as everyone wants to vilify Goldman Sachs, I wonder how much of this decision is due to pressures from political sources to make Goldman the whipping boy." (WHOLE FOR PART (everyone), AGENT FOR ACTION (vilify), INSTITUTION FOR PERSONS (Goldman Sachs, Goldman), SIMPLIFIED EVENT FOR COMPLEX SUB-EVENTS (decision, pressures), DEFINING PROPERTY FOR PERSONS (political sources), RESULT FOR ACTION (whipping boy))

In Example (7a), a complex metaphor/metonymy blend compares anger to heat, in which the physiological response (rising temperature) stands metonymically for the emotion: anger. This vivid presentation of anger as heat then helps to build the case that the government's charges are harsh or aggressive. In tandem, the reference to the crime as rich pay and profits downplays the actual crimes that were committed that go beyond exorbitant compensation. Furthermore, Goldman Sachs (designated metonymically by the abbreviated Goldman, which also connotes familiarity/closeness), is referred to as the whipping boy (substitution of RESULT FOR ACTION and the downgrade from "man") who is vilified (substitution of AGENT FOR ACTION), which again leads to a sympathetic portrayal because the term typically means undeservedly.

In the example below, Martha Stewart's positive qualities and background are discussed.

\section{Text 9. Martha Stewart convicted on all counts}

(9a) Raised in New Jersey in a family of six children, Stewart learned her homemaking skills from her mother and gardening from her father, according to her Web site. She earned a bachelor's degree in history and architectural history at Barnard College and worked as a model to pay her tuition, then became a stockbroker on Wall Street after graduating. She started on the path that would bring her fortune by developing a catering business in 1972. (DEFINING PROPERTY FOR CATEGORY (family of six children, mother, father), WHOLE FOR PART (homemaking skills), PLACE FOR STATUS (Barnard College), AGENT FOR ACTION (model), PROFESSION FOR PERSON (stockbroker), PLACE FOR INSTITUTION (Wall Street), SIMPLIFIED EVENT FOR COMPLEX SUB-EVENTS (path))

In Example (9a) metonymies such as DEFINING PROPERTY FOR CATEGORY and PLACE FOR STATUS, among others, lead to a positive representation. Interestingly, the fact that Stewart was a stockbroker (and therefore knows the rules and the definition of insider trading) is lost 
in the midst of all the other metonymies and the journalist does not pick up on or highlight this important and relevant detail. Instead, the comment is included as part of her other signs of privilege such as the fact that Stewart went to (expensive, highly prestigious) Barnard College. This inclusion of so many seemingly irrelevant details, also called functional irrelevance or over-completion, is a mode of description in which seemingly "irrelevant" details, that are relevant within a more general negative or positive portrayal of a person or group, are used (Van Dijk, 1991, p. 185). This can be understood in light of the violation of Grice's Cooperative Principle and his maxim of quantity, which dictates that we give as much information as is required and no more than is required. Violations (flouting) of this maxim can serve the purposes of misleading or providing a specific implicature, that is, implying something that is not expressed directly (Grice, 1989, p. 28). The use of over-completion (through the use of metonymy) in this example is a competent strategy to frame Martha Stewart as privileged and serves to humanize her so that she is seen as a person and not a criminal. In Examples (10a) and (10b) (below), once again the defendants are seen in a positive light through metonymy.

\section{Text 10. SEC charges CEOs of Fannie Mae, Freddie Mac}

(10a) Two former CEOs at mortgage giants Fannie Mae and Freddie Mac on Friday became the highest-profile individuals to be charged in connection with the 2008 financial crisis. (JOB FOR PERSONS (CEOs), INSTITUTION FOR PERSONS (Fannie Mae and Freddie Mac), DEFINING CATEGORY FOR PROPERTY (mortgage giants, highest-profile individuals))

(10b) According to the lawsuit, Fannie and Freddie misrepresented their exposure to subprime loans in reports, speeches, and congressional testimony; (INSTITUTION FOR PERSONS (Fannie and Freddie), RESULT FOR ACTION (exposure))

In the above examples not only are the defendants portrayed as high-status individuals (former CEOs, giants), but the fact that the government-sponsored enterprises of Fannie Mae (Federal National Mortgage Association) and Freddie Mac (Federal Home Loan Mortgage Corporation) profited greatly from selling subprime mortgages is converted to being exposed to subprime mortgages. Note the use of abbreviations that hide the actual purpose of the company and the fictitious, "friendly" names in the service of metonymically humanizing these large corporations. The first instance of the abbreviations lists them as Fannie Mae and Freddie Mac in Example (10a) but then they are reduced metonymically to Fannie and Freddie in Example (10b), nicknames that serve to increase the level of familiarity, intimacy, and trust we have in these institutions. Also the verb misrepresented is used instead of lied about and demonstrates how language normally associated with crimes is avoided in corporate crime reports. Furthermore, there are two linguistic processes which represent a means of using metonymy. First, the nominalization exposure changes the verb (exposed) (as in they were exposed) to a noun (exposure), which downgrades the force of the action. ${ }^{8}$ Second, they were exposed is a form of the passive which does not name an agent who was responsible for the exposing. Moreover, the metonymy exposure stands for all the events associated with subprime mortgages and these companies, namely, the selling of them to vulnerable individuals without full disclosure of the process and its possible consequences. The above examples support a narrative of "it's not their fault" and once again, the discourse of crime is not employed here and therefore the reader has the impression that there is no crime and therefore no one to blame. 


\section{Analysis of CEO crime reports: Image}

The next examples reveal how images work together with texts to present CEOs/Wall Street in a positive light.

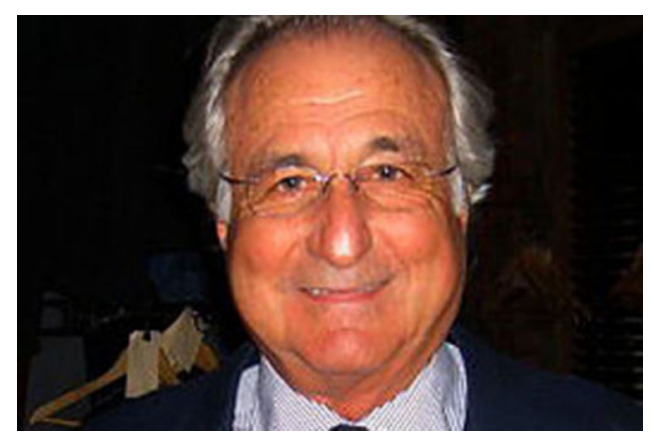

Photo 3. Bernie Madoff. Retrieved from: http://online.wsj.com/article/SB122903010173099377.html

Bernie $e^{9}$ Madoff

METONYMY: DISTANCE FOR (UN)FAMILIARITY(close-up for intimacy = "one of us," familiarity), CLOTHES FOR STATUS (suit)

According to Van Leeuwen, in pictures, distance becomes symbolic. "People shown in a 'close-up' are shown as if they are 'one of us'" (2008, p. 138), that is, familiarity, closeness, positive affect. In Photo 3, Bernie Madoff's close-up smiling photograph hardly conveys the fact that this man is responsible for a crime that, among other things, caused hundreds of retirees to lose their pensions and cost hundreds of jobs. Furthermore, the photo was not taken after he was indicted or convicted, and is not a mug shot. The close view and direct gaze and smile of Madoff help to present the viewer with an image of a nice, benevolent, grandfatherly type - wearing a suit and tie, which is a metonym for high status.

In Photo 4, the Goldman Sachs building stands metonymically for the institution itself, and the fact that it is large/towering, depicted with an upward camera angle, leads to the conceptual metaphor POWER/STATUS IS UP. This technique by which metonymy leads to metaphor, alluded to above (p. 6), has been noted by various researchers (Barcelona, 2011; Hidalgo- Downing \& Mujic, 2011; Mittelberg \& Waugh, 2009; Urios-Aparisi, 2009). ${ }^{10}$

In the example here, the metonymic-metaphorical image portrays the power and stature of the accused firm and demonstrates how the sign of economic capital may be just as effective as the thing itself (Thwaites, Davies, \& Mule, 2002, p. 198). This image (through complex interaction of metonymies and metaphors such as of DISTANCE FOR (UN)FAMILIARITY, CAMERA ANGLE FOR STATUS, PLACE/OBJECT FOR INSTITUTION, SIZE FOR STATUS) denotes Goldman Sachs to be both metonymically and metaphorically on top of the world, in contrast to the dramatic fall of the company's reputation. Additionally, because the architecture of the building is special, this symbolizes that the company is special, and this is presented clearly by the way the photo was taken to highlight its exceptional architectural features. Moreover, the caption beneath the photo shows how the image and text work together to let us know (with the word new) that this building has not been around very long and therefore this company has recently had enough money to build such a grand building. Again, we have text and image working in tandem to characterize the defendants positively. 


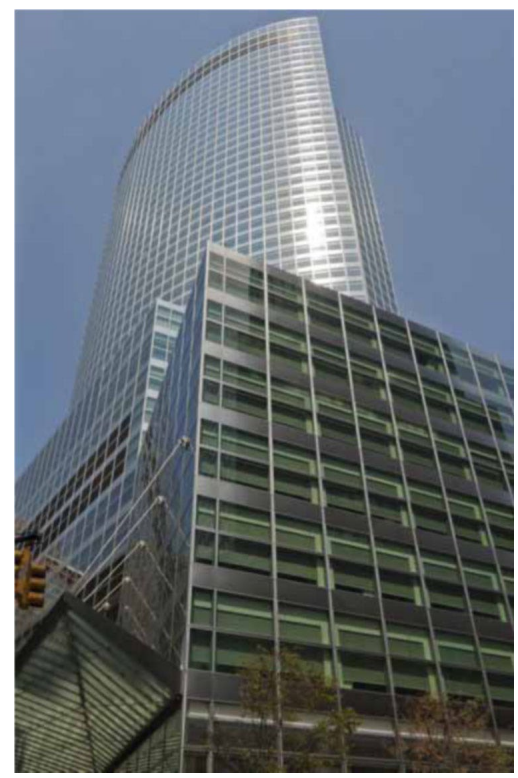

Photo 4. The new Goldman Sachs Group headquarters in New York's lower Manhattan. This photo is similar to the photograph in the original article. View the original photo at: http://online.wsj.com/article/SB10001424052702303491304 575187920845670844.html?mod=WSJ_hpp_LEFTTopStories

METONYMIES (with metaphors): DISTANCE FOR (UN)FAMILIARITY (close), CAMERA ANGLE FOR STATUS (upward), PLACE/OBJECT FOR INSTITUTION (building for company), SIZE FOR STATUS (big)

In Photo 5 the metonymy of BODY PART FOR ACTION focuses on Lloyd Blankfein's finger as it points to someone out of view. Because the photo is in the context of the court hearing about the case of securities fraud against Goldman Sachs, we know that the persons on the other side of the finger pointing are the government lawyers (working for the SEC). Therefore, the underlying message of the photo is not that Lloyd Blankfein or Goldman Sachs is to blame, but instead, the recipient, metonymically represented by the finger pointing, a member of the government, is, and thus, metonymically, the government is to blame. These photos and graphics provide more evidence for the notion that while the media is assumed to speak (metonymically) on behalf of the public, they also represent powerful capital interests such as Goldman Sachs. This should not be entirely surprising given that the source is the Wall Street Journal (owned at the time by Rupert Murdoch, one of the richest men in the world), whose readers include among others, Wall Street brokers, bankers, and corporate executives.

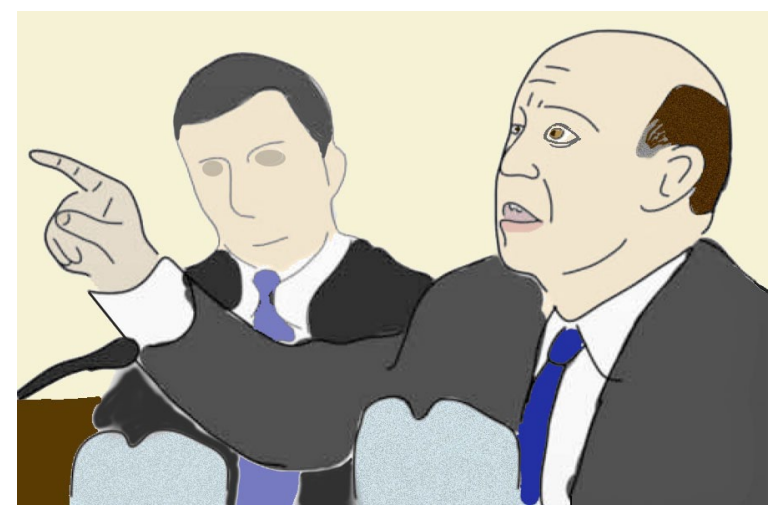

Photo 5. CEO Lloyd Blankfein has drawn heat for Goldman's rich pay and profits in the wake of the taxpayer bailout of the financial system. This drawing is similar to the photograph in the original article. The original photo appeared at: http://online.wsj.com/article/SB1000142405270230349130457518792084 5670844.html?mod=WSJ_hpp_LEFTTopStories 


\section{METONYMY: BODY PART FOR ACTION (pointing finger for blame)}

The last photo demonstrates the metonymies of AGENT FOR STATUS (having a well-known lawyer represents high status) and OBJECT FOR STATUS (Martha is wearing a fur stole, a known index of wealth) and supports the text's narrative that she is a privileged member of society. The accompanying caption to the photo again demonstrates use of metonymies to complement the photo's positive representation: faced is used to downgrade the result from more harsh terms such as charged or indicted with, and sale is a neutral term that erases the defining property of the crime $=$ illegal.

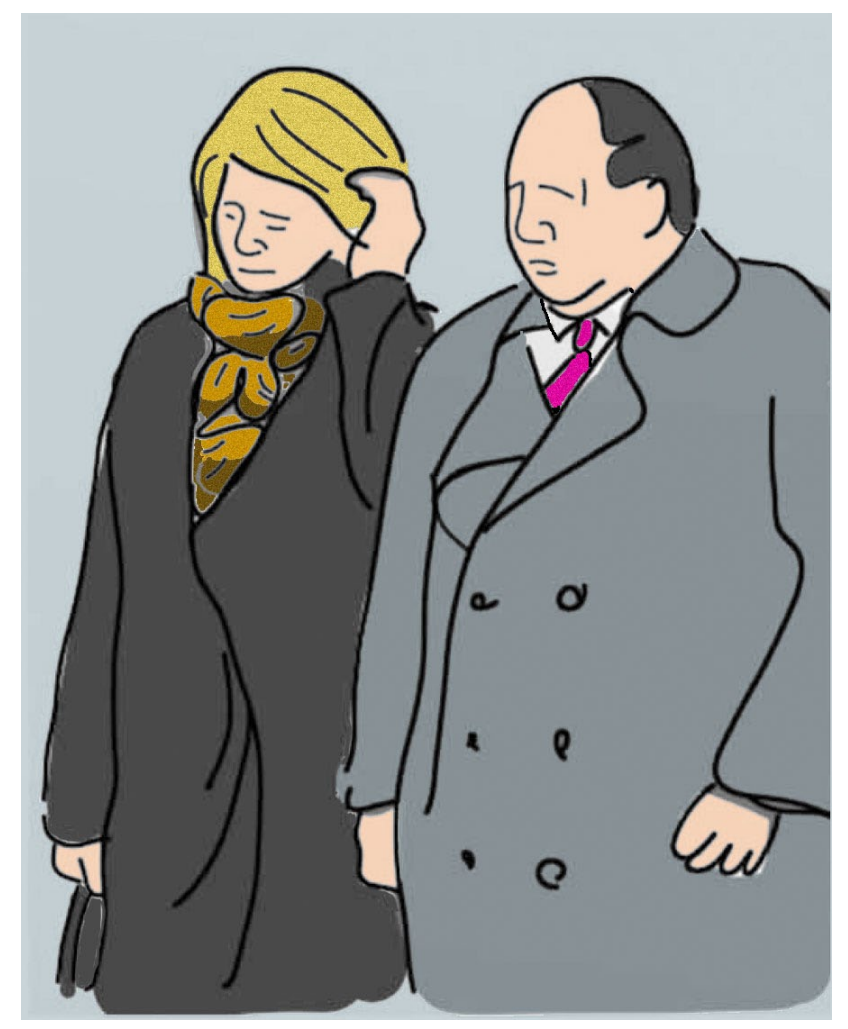

Photo 6. Stewart, 62, was convicted on all four counts of conspiracy, obstruction of justice and lying to federal investigators that she faced in connection with her Dec. 27, 2001, sale of ImClone Systems Inc. stock. This drawing is similar to the photograph in the original article. The original photo appeared at: http://www.washingtonpost.com/ac2/wp-dyn/A33685-2004Mar5

\section{METONYMIES: AGENT FOR STATUS (lawyer), OBJECT FOR STATUS (fur)}

Most images of the accused individuals in the CEO crime reports are seen in photographs depicting the defendants in environments not associated with criminal activity (such as home, the street) and most involve the participants in some type of action (such as pointing at SEC, walking with their lawyer). It is important to make note of this pattern later when looking at images found in Latino crime reports.

In summary, we can see by the above examples that corporate criminals are represented in a largely positive way and metonymy plays a large role in this representation. Because corporations are complex and any allegation against them may require long-drawn-out inquiries, they are often under-reported and there is an absence of the usual crime definers' voice (the police). It is replaced 
by powerful legal people familiar with the sector (such as SEC) who are often on the side of the defendant and who are the ones quoted by the media, which leads often to the use of language not normally associated with crimes and therefore the readers perceive the crimes as less severe. Because corporations are part of the power structures of our societies, and the mass media are owned by corporations and funded by their advertisers (other corporations), corporations control how they are presented in the mass media (Mayr \& Machin, 2012, p. 203). We will now see how crime reports differ when the defendants are those who have no power or access to the media.

\section{Analysis of Latino crime reports: Text}

In order to truly comprehend the biased treatment of Wall Street/CEOs, it is necessary to look (albeit briefly) at reports that depict crimes committed by individuals that are viewed as "Them," come from less-privileged backgrounds, and are considered "outsiders." This counter-analysis serves to demonstrate that under similar circumstances (being accused/convicted of a crime) people in power are not treated the same way discursively and visually as those who are oppressed by those in power. One such group that is often represented negatively in media discourse (particularly prominent during an economic downturn) is migrants, and more specifically Latino undocumented migrants (aka "illegal immigrants"). The majority of the subjects in the articles are from Mexico with others from Guatemala, Colombia, and other unidentified Latin American countries. For a detailed list of metonymies extracted from 16 texts from the years 2008-2011 see Table A2.

The following examples from the texts illustrate the use of metonymy to present Latinos negatively in crime reports. According to Table A2, the most common metonymies for Latino crime reports are DEFINING PROPERTY FOR CATEGORY and NON-HUMAN FOR HUMAN (as per Santa Ana, 1999, 2002, 2013). These metonymies are largely represented by the following terms: illegal immigrant, illegals, and illegal aliens. Here below we list some examples of the use of metonymy to represent Latinos negatively in crime reports:

\section{Text 1: Illegal immigrant charged in rape of girl}

(1a) "This suspect sexually assaulted a young innocent girl and this is yet another example of a violent crime committed by an illegal alien in Maricopa County," Sheriff Joe Arpaio said. (DEFINING PROPERTY FOR CATEGORY (suspect, young innocent girl, violent crime, illegal), NONHUMAN FOR HUMAN (alien), DEFINING PROPERTY FOR CATEGORY (Sheriff))

In this text of only 164 words (including the title), there are four metonyms referring to the legal status of the perpetrator, such as illegal alien and illegal immigrant seen above, which has nothing to do with the crime being reported but serves as part of the overall semantic strategy of the article: positive "Us" versus negative "Them" representation. This form of over-completion and violation of Grice's maxim of quantity helps to reinforce the idea of group crime. That is, this crime is treated as a stereotype, for which the whole Latino/immigrant community tends to be blamed and represents a prominent proposition in racist ideology (Van Dijk, 1991, p. 100). The rhetorical strategy of first presenting the crime and then highlighting the most negative parts (sexual/ly assault/ ed) is done four times and rape is mentioned twice during the article as well as two references to the age and "innocence" of the victim). This is followed by the connection to the macro context and the larger issue as expressed by Sheriff Arpaio: "this is yet another example of a violent crime committed by an illegal alien in Maricopa County," in Example (1a), which works to serve the purpose of negatively representing "illegal" immigrants. Sheriff Joe Arpaio is quoted to give credibility to the investigation. 
In contrast, in this example and in the 15 other Latino crime reports examined for this paper there were no quotations by the perpetrators or non-white victims. While we cannot say that the voice of the migrant defendants is never heard, since this is a sampling of the texts and our purpose is not to characterize all depictions of migrant defendants (but see Santa Ana 2013, which comes to the same conclusion on the basis of a large corpus of network evening news), it is nevertheless indicative that in our data these defendants are not quoted (which supports Santa Ana's 2013 findings that Latinos are "'rarely' interviewed as news sources in local newscasts" and are "virtually invisible as anchors, reporters and subjects") (p. 12). In contrast, the voice of the CEOs is ubiquitous in all the reports analyzed for the CEO crimes section. Moreover, in CEO crime reports the voice of law enforcement officers is largely absent and is replaced by lawyers of the defendants, legal organizations such as SEC, and their family members and colleagues. In the above article, as in many of the Latino crime reports (and in most street-crime reports as opposed to corporate crimes), the voice of law enforcement rings loud and clear. According to Mayr and Machin this is because the police have a central role as crime definers that is reinforced by their close symbiotic relationship with the media $(2012$, p. 168). In their quest to make themselves look good and to advocate for their own personal and political issues (e.g. anti-immigration laws such as Arizona SB1070), pertinent information is deleted, left out, or downplayed. In the case of the above article Sheriff Arpaio's comment ignores the fact that the suspect has been CHARGED and not CONVICTED. In Example (1a) he is first called a suspect by Sheriff Arpaio and then in the second clause he uses the verb committed, which assumes that the suspect has been judged guilty, when in fact, he has not. As a man who works for a law enforcement agency, Sheriff Arpaio knows the concept of "innocent until proven guilty" but denies this right of due process to the accused and capitalizes on the fact that much of the public will not notice this distinction or will be in agreement with this framing. This pattern of "guilty unless proven innocent" occurs repetitively in the Latino crime reports.

In Text 3 (below) metonymies are used again in the process of passivization to dehumanize and depersonalize the defendants.

\section{Text 3. BCSO arrest illegals for home burglaries}

(DEFINING PROPERTY FOR PERSON (illegals [note the use of the adjectival noun, a grammatical metonym (see footnote 9), which reinforces the defining property = illegal])

(3a) Sheriff Frank McKeithen has released additional information Tuesday morning concerning the arrest of four individuals on Monday on burglary charges. The four were spotted in a vehicle that law enforcement was looking for and believed was being used in numerous home burglaries. (NUMBER FOR PERSON (The four) ${ }^{11}$ ).

(3b) After being found to be in the USA illegally, Ruiz-Toledo was processed for removal in September of 2009. Comacho-Ruiz and Chirinos-Rivera were found to be illegal in the USA, have had Holds for ICE placed on them, and are to be processed for removal by the Bay County Sheriff's Office $287 \mathrm{~g}$ Task Force. (PART FOR WHOLE (Ruiz-Toledo, Comacho-Ruiz, Chirinos-River, processed [twice]), ACTION FOR RESULT (removal [twice]), INSTITUTION FOR PERSONS (ICE))

Above, the headline has again changed the adjective illegal to a noun and metonymically classifies the person as such. The metonymy of NUMBER FOR PERSON (the four) in Example (3a) demonstrates a type of assimilation (also known as aggregation) and makes the individuals become a group by quantifying the participants and treating them as statistics (Van Leeuwen, 2008, p. 37). On the other hand the metonymy (used twice in the article) of ACTION FOR RESULT (processed for removal) 
masks the actual events of the arrest (which may include handcuffing, fingerprinting, searching, photographing, and eventually filling out paperwork for deportation) and perhaps other events such as manhandling or beating of the individual. Additionally, note the metonymic use of the last name to refer to the defendant. This is generally the norm in crime reports, and it is noteworthy that there are no uses of $M r$. to refer to Latino defendants in the Latino crime report texts, while there are 95 tokens of $\mathrm{Mr}$. in the CEO crime reports.

In Text 6 (below), the metonymy of SIMPLIFIED EVENT FOR COMPLEX SUB-EVENTS (speaks stands for all the skills involved in knowing the English language and communicating in it) is used effectively to represent the participant negatively and highlight the ethnicity (no English) of the individual and, by metonymy, an immigrant, and by further metonymy, Latino.

The headline of the article highlights the nationality of the offender (Mexican). This nationym denies the subject's life in the USA and is a de-spatialization, which defines groups in terms of geographical or metaphorical space and makes them appear as "displaced" (Hart, 2010, p. 58). De-spatializations such as these attempt to distinguish the "non-native" from the "native" population and succeed in distancing the offender from "us" the (non-Latino) reader. Furthermore, the use of Mexican is a genericization that places this story into a news frame in which Mexicans (in particular, those who are not legal immigrants) are a contemporary problem in the USA. The use of such a generic term serves to give a racist angle to the story (Mayr \& Machin, 2012, p. 71). The fact that Mexican is placed first (before illegal) gives importance to the country of origin and is therefore a sign of racist discourse emphasizing that what is important is where he originates from. Another strategy used to send a message to the readers is the phrase fond of US life, which helps to support the narrative of burden and the message that the text is trying to send, which is that immigrants keep coming back because they like living in the USA and the USA is not doing enough to keep them out. Moreover, the phrase led a solitary existence is another example of over-completion and the use of unnecessary information used to complement the overall narrative of "Other."

Text 6. Mexican illegal arrested in Murrysville carjacking attempt fond of US life

(DEFINING PROPERTY FOR CATEGORY (Mexican, illegal)

(6a) By all accounts, Baltazar, who speaks no English, led a solitary existence. (SIMPLIFIED EVENT FOR COMPLEX SUB-EVENTS (by all accounts, speaks, solitary existence)

In the last text (below), we see the forefronting of the law enforcement status (deputies) in opposition to the illegal status of the accused individual; and the use of Sheriff Joe Arpaio's before deputies gives elite status metonymically to the deputies because they work for him. Here the selected quoting of elites (once again, Sheriff Joe Arpaio) is employed to highlight the supposed dangers that illegal immigrants place on society and link them to the political issues of importance (in this case, securing the border). The use of gained access (twice) makes it seem that he got there illegally or for some illicit purpose - but he was a worker at the plant, a fact which is hidden by the participial phrase (working inside). Thus, the metonyms serve the function of sending the political message desired by this particular law enforcement officer for his own political gains and constitute manipulation of public opinion.

\section{Text 16. Illegal immigrant working inside nuke plant arrested}

16a) Maricopa County Sheriff Joe Arpaio's deputies arrested an illegal immigrant working inside the Palo Verde Nuclear Plant, the nation's largest nuclear plant and one of the most closely monitored in the 
country. (DEFINING PROPERTY FOR CATEGORY (Maricopa County Sheriff Joe Arpaio's deputies, illegal immigrant))

16b) "To some extent," Arpaio says, "security at this nuclear power plant worked." But still, an illegal immigrant was permitted to gain access to this facility. This raises the question: how safe is Palo Verde really if an illegal alien can gain access to this nation's largest nuclear power facility? (DEFINING PROPERTY FOR CATEGORY (illegal immigrant), NON-HUMAN FOR HUMAN (alien))

\section{Analysis of Latino crime reports: Image}

The main point of interest in the images in the Latino crime reports lies in the striking contrast between these images and those of the CEO texts. Whereas the accused individuals in the CEO crime reports are seen in photographs depicting the defendants in some type of action not associated with being in the custody of the police (such as pointing at a SEC lawyer, walking with a lawyer), the photographs depicting Latino defendants are mug shots, such as in Photos 7 and 8. Mug shots, which are a standard way in which (suspected) criminals are recorded and also a typical feature of crime reports, follow a well-established pattern of representing metonymically only the face and part of the shoulders of the person photographed and highlighting the criminal nature of the subject by juxtaposing the features of the subject (such as no smile, unbecoming birth marks, hooded eyes, and wary expression as in Photo 7) with the mug shot frame. In addition, they are at more distance from the viewer than in, for example, the Bernard Madoff photo (Photo 3); in this case, then, the metonymy of DISTANCE FOR (UN)FAMILIARTY is used to show distance from, and thus no empathy, familiarity, closeness with, the subject. In the case of the mug shots found here, they bring out the features of the Latino subject (brown skin, brown hair, facial features as mentioned above), thereby creating the metonymy of DEFINING PROPERTY FOR CATEGORY, where Latino stands for criminal and, when compared with Photo 3, the unfavorable depiction of the accused stands in stark opposition to the grandfatherly image of an elderly white man with shining eyes, friendly, and smiling at the viewers. Although all subjects were accused of crimes (with only Bernard Madoff known to be convicted) the PART FOR WHOLE (positive or negative physical characteristics standing for the whole person) and DEFINING PROPERTY FOR CATEGORY (Latino for criminal, CEO for family/friendly man) metonymies create contrasting positive (Madoff)/negative (Latino) representations of these subjects that work together with the text to send an overall message about the social actors to the viewers.

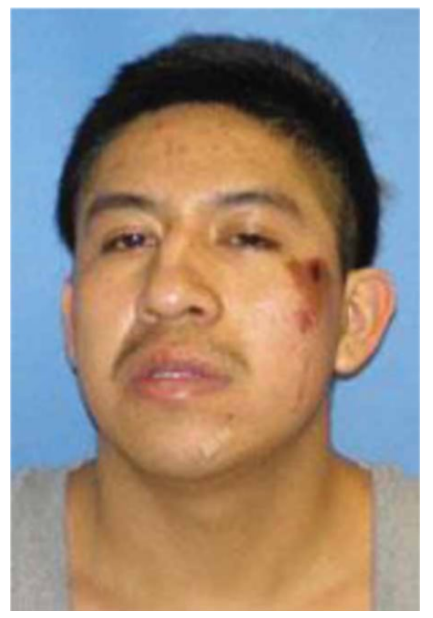

Photo 7. Credit: Murrysville Police Dept. Retrieved from: http://www.pittsburghlive.com/x/pittsburghtrib/news/westmoreland/s 675836.html 


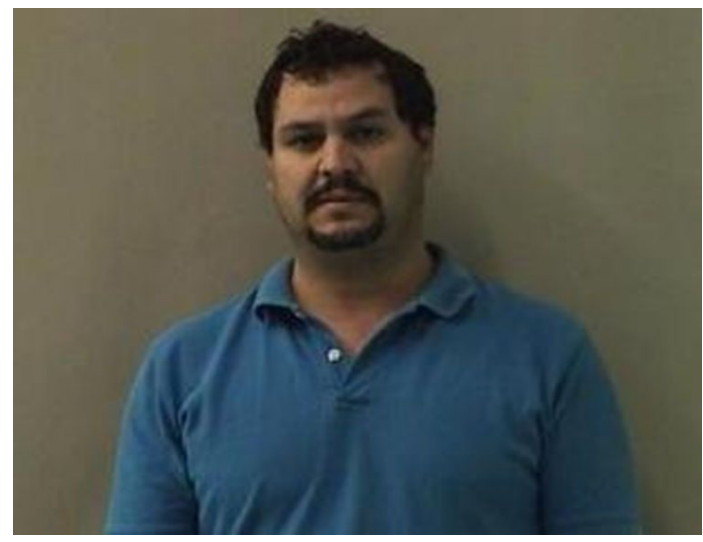

Photo 8. Credit: Bell County Jail. Retrieved from: http://www.kxxv.com/story/16419295/

illegal-immigrant-accused-of-sexually-assaulting-young-child-multiple-times

\section{Conclusion}

The multimodal nature of this analysis has provided valuable insights into media discourse about crime, due to its power to focus attention to both verbal and visual details (Mayr \& Machin, 2012, p. 225). This paper has demonstrated the ideological potential of metonymy, which contributes greatly to the negative/positive representation of Latinos/CEOs in crime reports. Although a more extensive analysis of the two different ways in which crimes committed by Wall Street/CEOs and "illegal" immigrants are talked about in the media needs to be done (Santa Ana 2013 is an excellent example of this), the examples provided here suggest that metonymies represent a ubiquitous but extremely subtle means that those in power use to direct attention to or away from events or actions. Some of the most frequent metonymies used for this purpose in our data (Tables A1 and A2) included DEFINING PROPERTY FOR CATEGORY/ PERSON(S), INSTITUTION/JOB FOR PERSONS, SIMPLIFIED EVENT FOR COMPLEX SUB-EVENTS (for CEOs), and DEFINING PROPERTY FOR CATEGORY/ PERSON(S), NON-HUMAN FOR HUMAN (for Latinos). By having access to the media, people in power (such as CEOs, their lawyers, and law enforcement officers) present a positive "Us," and in many of our examples, replace the discourse of crime with the language of a tragedy or accident. This in turn helps the reader to view the event in a non-criminal way, and allows CEOs and corporate criminals to be seen as unfortunate victims of nature or circumstance. The way these social actors are portrayed plays a large role in how the reader perceives these groups as a whole and the kinds of consequences that result (e.g. prison sentences they serve, government policies that are or are not put in place). Thus, as we know from various discussions around immigration, in the case of Latino crimes, the negative portrayal of Latinos in crime reports has been used as a rationale for unjust immigration laws and policies. On the other hand, the positive portrayal of CEOs has helped to continue laws and policies (such as de-regulation) that permit such abuses to occur. Although there are numerous ways in which one can transform the social practices of groups or individuals in media discourse, we want to underline that revealing the use of metonymy can raise consciousness about how media discourse contains underlying ideologies and contributes to the public's conceptualization of these groups. Furthermore, learning how to think critically to de-construct and de-mystify these ideologies is the first step in bringing about social justice and social change. 
Acknowledgments - The authors wish to thank Grace Fielder and Richard Ruiz for their help in early stages of this work, as well as Ron Breiger, David Machin and the comments from an anonymous reviewer for Critical Discourse Studies that led, we hope, to ameliorations of this paper.

\section{Notes on contributors}

Theresa Catalano has a PhD in Second-Language Acquisition and Teaching from the University of Arizona. She is currently assistant professor of Second-Language Education/Applied Linguistics at the University of Nebraska-Lincoln. She publishes across a range of academic journals with an interest in multimodality and critical metaphor analysis.

Linda R. Waugh is professor of French, English, Anthropology, Linguistics, and Language, Reading, and Culture at the University of Arizona. She is on the Executive Council of the Interdisciplinary PhD program in Second Language Acquisition and Teaching, Co-Director of the U.S. federally-funded Center for Educational Resources in Culture, Language and Literacy, and a member of the Advisory Board of Confluence: A Center for Creative Inquiry. She is also Executive Director of the Roman Jakobson Intellectual Trust.

\section{Notes}

1. There are others who incorporate metonymy with analyses that are close to CDA but with no explicit tie to CDA e.g. Santa Ana $(1999,2002)$.

2. Articles were selected within this time frame in order to limit the number of texts due to the scope of the paper, and to keep texts files in parallel time frames.

3. Google searches were used in order to provide a purposeful sampling of articles reporting crimes committed by both groups examined. To find articles featuring a particular group (such as CEOs or Latinos), lexical terms used to reference each group examined were searched (i.e. "CEO" "Latino" "illegal immigrant" "Hispanic" paired with a term associated with crime such as "accused" "convicted" "arrested").

4. Images were found in CEO articles Text 1, 2, 3, 5, 7, 8, 9 and Latino articles Texts 1, 4, 5, 6, 8, 15.

5. Note that each text is numbered according to its numbering in the appendix and that the headline accompanying the text is given with the number. In addition, examples are numbered according to the text they are from and order of appearance in the paper.

6. Note also the metonymic use of the nickname "Kristie" for the wife's first name, which creates familiarity/ closeness, positive affect, sympathy for her and, by metonymy, for him.

7. A scrum is a play in rugby in which the two sets of forwards pile together around the ball and struggle to gain possession of it; in this context, it has a negative connotation.

8. These are examples of what are called "grammatical metaphors" in Systemic Functional Linguistics (see Martin, 1992, pp. 406-417), but they are actually "grammatical metonyms" according to our definition of metonymy.

9. Notice the use of the nickname "Bernie," which has the same force as "Kristie" in example (5b).

10. While there are many examples in the literature of metaphor coming from metonymy, there do not seem to be examples of metonymy coming from metaphor (Barcelona, 2011; Benczes, 2011).

11. Four individuals followed in the next sentence by the four is a typical cohesive device; many cohesive devices, like this one, are metonymic in nature (Al-Sharafi, 2004).

\section{References}

Al-Sharafi, A. (2004). Chapter 4: Metonymy and text cohesion. Textual metonymy: A semiotic approach (pp. 109-135). New York, NY: Palgrave Macmillan.

Barcelona, A. (2011). Reviewing the properties and prototype structure of metonymy. In R. Benczes, A. Barcelona, \& F. J. R. Mendoza (Eds.), Defining metonymy in cognitive linguistics: Towards a consensus view (pp. 7-60). Amsterdam: John Benjamins. 
Barcelona, A., Benczes, R., \& Ruiz de Mendoza Ibáñez, J. (2011). Introduction. In R. Benczes, R. A. Barcelona, \& F. J. Ruiz de Mendoza Ibáñez (Eds.), Defining metonymy in cognitive linguistics: Toward a consensus view (pp. 1-6). Amsterdam: John Benjamins.

Benczes, R. (2011). Putting the notion of "domain" back in metonymy: Evidence from compounds. In R. Benczes, R. A. Barcelona, \& F. J. Ruiz de Mendoza Ibáñez (Eds.), Defining metonymy in cognitive linguistics: Toward a consensus view (pp. 197-215). Amsterdam: John Benjamins.

Benczes, R., Barcelona, A., \& Ruiz de Mendoza Ibáñez, J. (Eds.). (2011). Defining metonymy in cognitive linguistics. Amsterdam: John Benjamins.

Catalano, T. (2012). The denaturalization of Romanies in Italy: How language and image work together. The International Journal of the Image, 2(4), 159-172.

Catalano, T., \& Waugh, L. (2013). The language of money: How verbal and visual metonymy shapes public opinion about financial events. International Journal of Language Studies, 7(2), 31-60.

Charteris-Black, J. (2004). Corpus approaches to critical metaphor analysis. Basingstoke: Palgrave Macmillan.

Clinard, M. B., \& Yeager, P. (2006). Corporate crime. New Brunswick, NJ: Transaction Publishers.

Dirven, R. (2002). Metonymy and metaphor: Different mental strategies of conceptualization. In R. Dirven \& R. Porings (Eds.), Metaphor and metonymy in comparison and contrast (pp. 75-111). Berlin: Mouton de Gruyter.

Dirven, R., \& Pörings, R. (Eds.). (2002). Metaphor and metonymy in comparison and contrast. Berlin: Mouton de Gruyter.

Fairclough, N. (1992). Discourse and social change. Cambridge: Polity Press.

Fairclough, N., Graham, P., Lemke, J., \& Wodak, R. (2004). Introduction. Critical Discourse Studies, 1(1), 1-7.

Fowler, R., Hodge, R., Kress, G., \& Trew, T. (1979). Language and control. London: Routledge.

Gibbs, R. W. Jr. (1994). Chapter 7: Metonymy. In R. W. Jr. Gibbs (Ed.), The poetics of mind: Figurative thought, language and understanding (pp. 319-359). Cambridge: Cambridge University Press.

Gibbs, R. W. Jr. (1999). Speaking and thinking with metonymy. In K.-U. Panther \& G. Radden (Eds.), Metonymy in language and thought (pp. 61-76). Amsterdam: John Benjamin's Publishing Company.

Grice, H. P. (1989). Studies in the way of words. Cambridge, MA: Harvard University Press.

Gustafson, J. L. (2006). Cracking down on white-collar crime: An analysis of the recent trend of severe sentences for corporate officers. Suffolk UL Review, XL(3), 685-701.

Hart, C. (2008). Critical discourse analysis and metaphor: Toward a theoretical framework. Critical discourse studies, 5(2), 91-106.

Hart, C. (2010). Critical discourse analysis and cognitive science: New perspectives on immigration discourse. Basingstoke: Palgrave Macmillan.

Hidalgo-Downing, L., \& Mujic, B. K. (2011). The interaction of multimodal metonymy and metaphor in ICT advertising discourse: Meaning creation as a complex discourse process. Review of Cognitive Linguistics, 9(1), 153-178.

Hodge, R. I. V., \& Kress, G. (1988). Social semiotics. Ithaca, NY: Cornell University Press.

Jakobson, R. (1956). Two aspects of language and two types of aphasic disturbances. Republished in 1971, Selected Writings II. (pp. 239-259). The Hague: Mouton.

Khosravanik, M. (2010). The representation of refugees, asylum seekers and immigrants in British newspapers: A critical discourse analysis. Journal of Language and Politics, 9(1), 1-28.

Lakoff, G., \& Johnson, M. (1980). Metaphors we live by. Chicago: Chicago University Press.

Maalej, Z. (2007). Doing critical discourse analysis with the contemporary theory of metaphor: Towards a discourse model of metaphor. In C. Hart \& D. Lukes (Eds.), Cognitive linguistics in critical discourse analysis: Application and theory (pp. 132-158). Newcastle: Cambridge Scholars Publishing.

Machin, D., \& Mayr, A. (2012). How to do critical discourse analysis: A multimodal approach. Los Angeles: Sage. 
Martin, J., \& Ruark, E. (2010, July, revised 2011, February). The fiscal burden of illegal immigration on U.S. taxpayers. Federation for American Immigration Reform (FAIR). Retrieved from http://www.fairus.org/site/DocServer/USCostStudy_2010.pdf?docID $=4921$

Martin, J. R. (1992). English text: System and structure. Amsterdam: John Benjamins.

Mayr, A., \& Machin, D. (2012). The language of crime and deviance: An introduction to critical linguistic analysis in media and popular culture. New York, NY: Continuum International Publishing Group.

Meadows, B. (2007). Distancing and showing solidarity via metaphor and metonymy in political discourse: A critical study of American statements on Iraq during the years 2004-2005. Critical Approaches to Discourse Analysis Across Disciplines, 1(2), 1-17.

Mittelberg, I., \& Waugh, L. R. (2009). Metonymy first, Metaphor second: A cognitive-semiotic approach to multimodal figures of thought in co-speech gesture. In C. Forceville \& E. Urios-Aparisi (Eds.), Multimodal metaphor (pp. 329-356). Berlin: Mouton de Gruyter.

Musolff, A. (2012). Special feature: The study of metaphor as part of critical discourse analysis. Critical Discourse Studies, 9(3), 301-310.

Panther, K. U., \& Thornburg, L. L. (2003). Introduction: On the nature of conceptual metonymy. In K. U. Panther \& L. L. Thornburg (Eds.), Metonymy and pragmatic inferencing (pp. 1-22). Philadelphia, PA: John Benjamins Publishing Company.

Ruiz de Mendoza Ibáñez, F., \& Perez Hernández, L. (2003). Cognitive operations and pragmatic implication. In K. U. Panther \& L. L. Thornburg (Eds.), Metonymy and pragmatic inferencing (pp. 23-50). Philadelphia, PA: John Benjamins Publishing Company.

Santa Ana, O. (1999). Like an animal I was treated: Anti-immigrant metaphor in US public discourse. Discourse and Society, 10, 191-224.

Santa Ana, O. (2002). Brown tide rising: Metaphors of Latinos in contemporary U.S. public discourse. Austin: University of Texas Press.

Santa Ana, O. (2013). Juan in a hundred: The representation of Latinos on network news. Austin: University of Texas Press.

Thwaites, T., Davies, L., \& Mules, W. (2002). Introducing cultural and media studies: A semiotic approach. Houndmills: Palgrave.

Urios-Aparisi, E. (2009). Interaction of multimodal metaphor and metonymy in TV commercials: Four case studies. In C. Forceville \& E. Urios-Aparisi (Eds.), Multimodal metaphor (pp. 329-356). Berlin: Mouton de Gruyter.

Van Dijk, T. A. (1987). Mediating racism: The role of the media in the reproduction of racism. In R. Wodak (Ed.), Language, power and ideology: Studies in political discourse (pp. 199-222). Amsterdam: Benjamins.

Van Dijk, T. A. (1991). Racism and the press. London: Routledge.

Van Dijk, T. A. (2009). Critical discourse studies: A sociocognitive approach. In R. Wodak \& M. Meyer (Eds.), Methods of critical discourse analysis (pp. 62-86). London: Sage.

Van Leeuwen, T. (2008). Discourse and practice: New tools for critical discourse analysis. Oxford: Oxford University Press. 


\section{Appendix}

Table A1. Metonymies referring to CEOs in Wall Street/corporate crime reports.

\begin{tabular}{|c|c|c|c|}
\hline Metonymy & Category & Sums & Per cent of total metonymies \\
\hline \multicolumn{4}{|l|}{ Positive } \\
\hline & Defining property for person(s)/category & 85 & $32 \%$ \\
\hline & Institution for person(s) & 30 & $11 \%$ \\
\hline & Simplified event for complex sub-events & 30 & $11 \%$ \\
\hline & Profession for person(s) & 18 & $7 \%$ \\
\hline & Action for agent(s) & 16 & $6 \%$ \\
\hline & Part for whole & 14 & $5 \%$ \\
\hline & Result for action & 13 & $5 \%$ \\
\hline & Whole for part & 8 & $3 \%$ \\
\hline & Product for producer & 4 & $2 \%$ \\
\hline Total positive & & 218 & $82 \%$ \\
\hline \multicolumn{4}{|l|}{ Negative } \\
\hline & Defining property for person/s/category & 17 & $6 \%$ \\
\hline & Action for agent & 6 & $2 \%$ \\
\hline & Result for action & 6 & $2 \%$ \\
\hline & Simplified event for complex sub-events & 6 & $2 \%$ \\
\hline & Action for result & 5 & $2 \%$ \\
\hline & Part for whole & 4 & $2 \%$ \\
\hline & Place for responsibility & 3 & $1 \%$ \\
\hline Total negative & & 47 & $18 \%$ \\
\hline
\end{tabular}

Metonymies with tokens of two or fewer are not included. Numbers were rounded to nearest 10.

Table A2. Metonymies referring to Latinos in Latino crime reports.

\begin{tabular}{|c|c|c|c|}
\hline Metonymy & Category & Sums & Per cent \\
\hline \multicolumn{4}{|l|}{ Positive } \\
\hline & Defining property for category/person & 4 & $5 \%$ \\
\hline Total positive & & 4 & $5 \%$ \\
\hline \multicolumn{4}{|l|}{ Negative } \\
\hline & Defining property for category/person & 68 & $78 \%$ \\
\hline & Non-human for human & 9 & $10 \%$ \\
\hline & Part for whole & 3 & $3 \%$ \\
\hline & Result for action & 3 & $3 \%$ \\
\hline Total negative & & 83 & $94 \%$ \\
\hline
\end{tabular}

Metonymies with tokens of two or fewer are not included. Numbers were rounded to nearest 10. 